\title{
Article
}

\section{Challenges for Protected Areas Management in China}

\author{
Miao $\mathrm{He}^{1, *}$ and An Cliquet ${ }^{2}$ \\ 1 Law Faculty, Wuhan University, Wuhan 430072, Hubei, China \\ 2 Department of European, Public and International Law, Ghent University, 9000 Gent, Belgium; \\ An.Cliquet@UGent.be \\ * Correspondence: miao.he@whu.edu.cn
}

Received: 23 May 2020; Accepted: 14 July 2020; Published: 22 July 2020

\begin{abstract}
Protected areas are widely recognized as a cornerstone of biodiversity and natural resources management and sustainable development. Protected areas are a vital part of securing human prosperity and quality of life. In China, the legal framework for protected area management is scattered around various regulations. In order to better manage protected areas in China, the Chinese government has issued and revised some laws, regulations and policies on protected areas conservation and management. However, protected areas management is still facing some challenges. There is little legal literature on this issue and this paper tries to fill this gap. Firstly, it will briefly introduce the most relevant laws, regulations and policy on protected areas management. Secondly, it will analyze the recent challenges of protected areas management. Thirdly, some possible suggestions on how to better solve the recent challenges on protected areas management in China will be proposed. These suggestions include improving the management system, improving the relevant legislation, promoting public participation and establishing a diversified funding guarantee system.
\end{abstract}

Keywords: protected areas; national parks; conservation laws; China

\section{Introduction}

Protected areas have various values, including environmental, economic, scientific, social and cultural values [1] (pp. 15-19). If protected areas are managed well, they could be an efficient and effective means to address biodiversity loss, help buffer society from the effects of climate change and maintain the critical ecosystem services on which all societies depend [2]. The benefits of protected areas appear both at the global and local level. When the full range of ecosystem services is taken into account, the benefits of protected areas often exceed their costs [3] and extend spatially far beyond their boundaries [4] (pp. 31-47).

According to the World Database on protected areas, there are 248,716 protected areas globally (the situation in May 2020) [5]. According to the Aichi biodiversity target 11, the goal is to have at least $17 \%$ of effectively managed terrestrial protected areas and $10 \%$ of marine protected areas by 2020 [6]. The dashboard for Aichi target 11 on the Protected planet website shows a global coverage of $15 \%$ for terrestrial areas and $7 \%$ for marine areas. The effectively managed areas are much less: $5 \%$ for terrestrial areas and merely $1 \%$ for marine areas [7]. Many protected areas are thus often no more than 'paper parks'. The legal basis for protected areas consists of international, regional, national or local protected areas. International legal obligations for establishing and managing protected areas include the Ramsar Convention, the World Heritage Convention and the Biodiversity Convention [8].

In China, the basic target of conserving protected areas is not only to preserve natural ecosystems and biodiversity but also to guarantee the economic development of the surrounding areas [9] (pp. 143-164). China has established a system of in-situ conservation composed of nature reserves, national parks, scenic spots, forest parks, wetland parks, protected areas for aquatic germplasm 
resources and special marine protected areas. According to the World Database on protected areas, China has $15.62 \%$ of its territory covered by terrestrial protected areas $\left(1,461,913 \mathrm{~km}^{2}\right)$, out of which $2.14 \%$ has a management effectiveness evaluation (a 200,412.8047 $\mathrm{km}^{2}$ area assessed). For the marine area, there is a $5.48 \%$ coverage of protected areas $\left(48,126 \mathrm{~km}^{2}\right.$ of Marine Area Protected areas) with only $0.09 \%$ having a management effectiveness evaluation (a $832.712621 \mathrm{~km}^{2}$ area assessed) [10]. According to the 6th report of China to the Biodiversity Convention, within these protected areas, over $90 \%$ of terrestrial natural ecosystem types and $89 \%$ of national key protected wild animals and plant species have been protected [11]. More than 300 wild animals and more than 130 wild plants fall under the State's key protection in China [12] (p. 14).

By the end of 2017, there were more than 2750 protected areas of various types in China, including 469 national protected areas [13]. Protected areas in China can be divided into strict protection class, restricted utilization class and sustainable use class [14] (pp. 38-44). However, there is no official statistic on the number of each type of protected area. The classification and system composition of protected areas in China can be found in Table 1 below.

Table 1. Classification and System Composition of Protected Areas in China [14] (pp. 38-44).

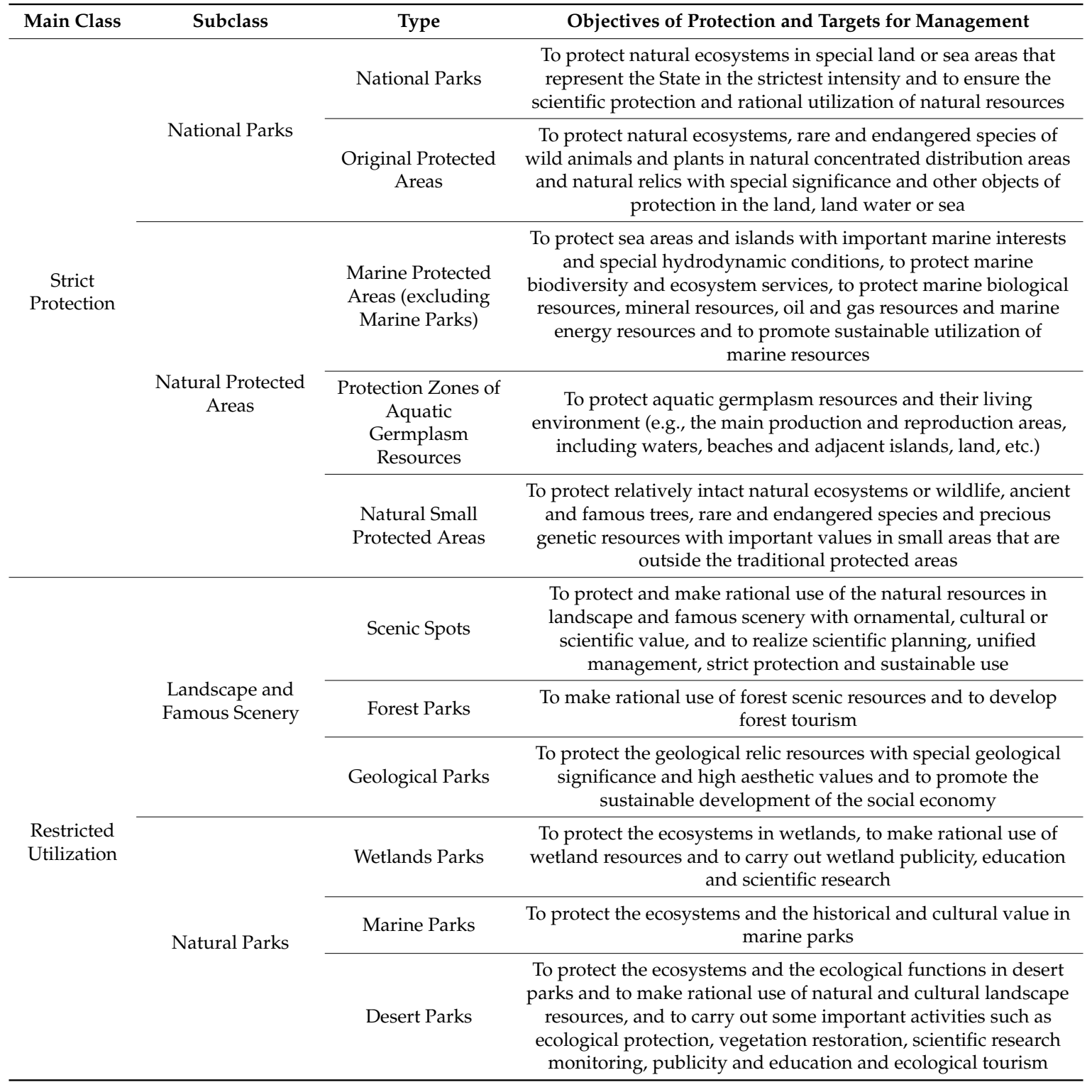


Table 1. Cont.

\begin{tabular}{|c|c|c|c|}
\hline Main Class & Subclass & Type & Objectives of Protection and Targets for Management \\
\hline \multirow{3}{*}{$\begin{array}{l}\text { Sustainable } \\
\text { Use }\end{array}$} & $\begin{array}{l}\text { Ornamental } \\
\text { Recreation }\end{array}$ & $\begin{array}{c}\text { Water Recreation } \\
\text { Areas }\end{array}$ & $\begin{array}{l}\text { To protect water and scenic resources, to improve the } \\
\text { environment, to achieve the balance among social benefits, } \\
\text { environmental benefits and economic benefits and to achieve } \\
\text { harmony between humans and nature }\end{array}$ \\
\hline & \multirow{2}{*}{ Resources Benefits } & $\begin{array}{c}\text { National Natural } \\
\text { Forests }\end{array}$ & $\begin{array}{l}\text { To protect the forests formed by natural formation and artificial } \\
\text { promotion of natural regeneration or germination, to maintain } \\
\text { and improve the ecological environment to meet the demand of } \\
\text { social and national economic development for forest products }\end{array}$ \\
\hline & & $\begin{array}{l}\text { National Public } \\
\text { Welfare Forests }\end{array}$ & $\begin{array}{c}\text { To protect the forest land that provides public welfare and social } \\
\text { products or services, to maintain and to improve the environment, } \\
\text { to maintain ecological balance, to protect biological diversity and } \\
\text { to meet the requirements of the ecological and social needs of } \\
\text { humans and sustainable development }\end{array}$ \\
\hline
\end{tabular}

This table shows that the objectives of protection, the targets for management, natural conditions and the social environment are different in the various types of protected areas. With the increasing number of protected areas, the objectives of protection in protected areas are becoming more diverse and complex. Different objectives of protection need different targeted, operational norms to be adjusted, so as to achieve an efficient management for protected areas.

According to the definition on protected areas in the "Regulations of the People's Republic of China on Nature Reserves" [15] (hereinafter, the Regulations), protected areas can be divided into core zones, buffer zones and experimental zones; core zone in protected areas in China belong to category la in the International Union for Conservation Nature protected areas management categories [16]. However, from a practical management perspective, many protected areas, with the function of biodiversity conservation and tourist reception, belong to category II: national park [17] (pp. 53-56). Although there are different levels and categories of protected areas in China, this classification system cannot clearly reflect the differences in management methods and inspection standards [17] (pp. 53-56). Based on the regulations, all the protected areas should be strictly managed.

In general, protected areas 'management' contains: (1) 'the process' (this is about undertaking four functions of management and the activities and operations that are associated with them. The four functions are 'planning', 'organizing', 'implementing' and 'controlling'.); (2) 'assembling and using resources' (these resources include people and their individual competencies, skills and lived experiences; financial resources; plant and equipment; and quality and relevant information from a range of sources.); (3) 'goal-directed manner' (the activity being managed has a purpose and direction within a strategic management context and aims to achieve a certain level of desired results.); and (4) 'in an organization' (it reflects that conserving biodiversity at the scale of protected areas and protected area system is a team effort.) [18] (p. 210).

Protected areas 'management' in this article refers to that the management organizations undertake all the relevant activities in protected areas after they are established. According to Article 22 [19] of the Regulations, the main responsibilities of management organizations for protected areas are (1) implementing all the relevant laws, regulations and policies; (2) formulating various management rules and uniformly managing protected areas; (3) investigating natural resources and establishing archives, organizing environmental monitoring and protecting natural resources and the environment in protected areas; (4) organizing or assisting the relevant departments to carry out scientific research in protected areas; (5) engaging in publicity and education on protected areas; (6) organizing visits and tours and other activities on the premise that the natural environment and resources are not affected. However, in practice, their responsibilities are not limited to these.

Generally speaking, protected areas conservation made a great progress in China. However, there are still some major challenges of protected areas management. This article formulates some recommendations that could promote, or at least help, to solve four main challenges of protected areas management from a legal perspective in China. Particularly, this paper tries to answer the following 
questions: (1) What are the relevant laws, regulations and policy on protected areas management in China? (Section 3); (2) What are the challenges in protected areas management? (Section 4); (3) What are possible suggestions on how to better solve the challenges on protected areas management in China? (Section 5).

\section{Methods}

There is little legal literature on the protected area management effectiveness in China. The methods used in this paper are classical legal research methods. They are predominantly a desktop study and an analysis of primary legal resources. These legal resources are selected relevant Chinese national or local laws and policies which are directly related with protected areas management, including the "Environmental Protection Law of the People's Republic of China" (2014 version), the "Regulations of the People's Republic of China on Nature Reserves" (2017 version), the "Forest Law of the People's Republic of China" (2009 version), the "Outline of the Development Plan for Nature Reserves in China (1996-2010)", the "Guidance on Establishing a System of Protected Areas with National Parks as the Main Body". The research also contains an in-depth literature review in particular of research papers. All the legal resources and literature were chosen to answer the research questions.

This paper provides an overview of the main laws, regulations, policies and practices relevant to the protected areas management in China. The discussion part analyzes the challenges of protected areas management, including institutional barriers, incomplete legislation, insufficient public participation and a deficiency of funding for protected areas. This discussion part is based on a literature study. In the section with possible suggestions for better protected areas management in China, four possible suggestions are proposed. These suggestions aim to improve the management system, to improve the relevant legislation, to promote public participation and to contribute to establish a diversified funding guarantee system. The suggestions are based on the legal analysis done in the previous sections and on a literature study.

\section{Results: Laws, Regulations and Policy on Protected Areas Management in China}

\subsection{Fundamental Laws}

The "Constitution of the People's Republic of China" [20], which is regarded as the fundamental law in China, points to the protection for natural resources and the general ownership of natural resources in China. According to Article 9 "Mineral resources, water, forests, mountains, grassland, unreclaimed land, beaches and other natural resources are owned by the State, that is, by the whole people, with the exception of the forests, mountains, grassland, unreclaimed land and beaches that are owned by collectives in accordance with the law. The State ensures the rational use of natural resources and protects rare animals and plants; the encroachment or derogation of natural resources by any organization or individual by whatever means is prohibited". Regarding scenic areas that are culturally significant, Article 22 of the Constitution provides that "the State protects sites of scenic and historic interests, valuable cultural monuments and other important historical and cultural heritage".

The "Environmental Protection Law of the People's Republic of China" (1989 version) [21] is widely accepted as the fundamental environmental law in China. Article 17 points out the duty of the governments for environmental protection [22]. Specifically concerning nature reserves [23] and other zones, Article 18 states: "Within the scenic spots or historic sites, nature reserves and other zones that need special protection, as designated by the State Council, the relevant competent department under the State Council, and the people's governments of provinces, autonomous regions and municipalities directly under the Central Government, no industrial production installations that cause environmental pollution shall be built; other installations to be built in these areas must not exceed the prescribed standards for the discharge of pollutants. If the installations that have been built discharge more pollutants than are specified by the prescribed discharge standards, such pollution shall be eliminated or controlled within a prescribed period of time." [24] The relationship between utilization and protection for natural resources is briefly discussed in Article 
19. It states "Measures must be taken to protect the ecological environment while natural resources are being developed or utilized." [25].

\subsection{Regulations for Nature Reserves}

Although there are several general provisions in the Constitution, the Environmental Protection Law and other laws in particular areas of natural resources, it is disappointing to find that 'protected areas conservation' was not safeguarded at the level of 'Law' [26]. The "Regulations of the People's Republic of China on Nature Reserves" [15] (hereinafter, the Regulations) are the most important regulations for protected areas protection under Chinese jurisdiction. These Regulations aim to strengthen the construction and management of protected areas and protect the natural environment and natural resources. The direct goal of the effective conservation of protected areas is to conserve natural resources and the environment and to achieve sustainable management of ecosystems and biodiversity. The interests of local people and the local economy shall thereby be properly considered to realize the direct goal. The Regulations emphasize that "The local economic construction, the production activities and everyday life of local residents shall be properly considered when the nature reserves are established and managed." [27] Chapter two focuses on protected areas establishment. Protected areas management is specifically addressed in chapter three. In this chapter, Article 21 of the Regulations points out that national protected areas shall be managed by the relevant administrative departments for protected areas under the people's governments of the provinces, autonomous regions and municipalities or by the relevant administrative departments of protected areas under the State Council. Protected areas at local levels shall be managed by the relevant administrative departments of protected areas under the local people's governments at or above the county level. The competent administrative department of the protected areas shall set up a special administrative organ with professional and technical personnel to be responsible for the specific management work in protected areas. However, there is no provision that clearly clarifies which specific department is responsible for a certain type of protected areas. Another important problem is that even though a protected area belongs to a national protected area, but is situated in more than one province, autonomous region or municipality, there could be some management interests' conflicts among these administrative areas. This will be specifically discussed in Section 4.1.

Chapter four of the Regulations refers to the legal liability that anyone or any unit shall bear if anyone or any unit violate the Regulations. It is noted that Article 26 and 27 point out the forbidden activities in protected areas, and Article 32 and 33 explain the general punitive measures for forbidden activities within protected areas.

The Regulations point out that the interests of local residents should be properly considered [15], but the Regulations do not mention how to consider the interests when conflicts occur. The Regulations oblige the different levels of governments to arrange for the proper settlement for local people, but do not point out what kind of settlement this should be. The Regulations also prescribe punitive measures for forbidden activities [28], but do not mention who examines the infringements on the law. However, other laws and regulations mentioned below have supplemented the Regulations.

\subsection{Other Relevant Laws and Regulations}

Other relevant laws and regulations on endangered species, forests, mineral resources, special marine protected areas, pollution and prevention and control of desertification also provide some provisions on protected areas management. The detailed information can be found in Table 2 below. 
Table 2. Other relevant laws and regulations.

\begin{tabular}{|c|c|c|}
\hline Law & Article No. & Content \\
\hline & & Laws on Endangered Species \\
\hline \multirow{4}{*}{$\begin{array}{l}\text { Law on the Wildlife } \\
\text { Protection of the } \\
\text { People's Republic of } \\
\text { China [29] }\end{array}$} & Article 12 & $\begin{array}{l}\text { (...) The people's governments at or above the provincial level shall delimit } \\
\text { relevant nature reserves in accordance with the law to conserve wildlife and their } \\
\text { important habitats and protect, restore and improve the living environment of } \\
\text { wildlife. Where the conditions for the delimitation of relevant nature reserves are } \\
\text { not met, the people's governments at or above the county level may conserve } \\
\text { wildlife and their habitats by delimiting no-hunting (or no-fishing) zones or } \\
\text { prescribing closed hunting (or fishing) seasons or other means. } \\
\text { Human disturbances threatening the living and breeding of wildlife, such as } \\
\text { introducing alien species into relevant nature reserves, creating pure forests, and } \\
\text { excessively spraying pesticides, shall be prohibited or restricted. The relevant } \\
\text { nature reserves shall be delimited and administered in accordance with the } \\
\text { provisions of relevant laws and regulations. }\end{array}$ \\
\hline & Article 13 & $\begin{array}{l}\text { (...) It shall be prohibited to construct, in relevant nature reserves, any projects } \\
\text { which are not allowed to be constructed under relevant law and regulations. (...) }\end{array}$ \\
\hline & Article 20 & $\begin{array}{c}\text { It shall be prohibited to hunt or catch wildlife or otherwise disturb the living and } \\
\text { breeding of wildlife within the relevant nature reserves and the no-hunting (or } \\
\text { no-fishing) zones or during the closed hunting (or fishing) seasons, except as } \\
\text { otherwise specified by laws and regulations. (...) }\end{array}$ \\
\hline & Article 45 & $\begin{array}{l}\text { Whoever, in violation of Article 20, Article 21, paragraph } 1 \text { of Article 23, or } \\
\text { paragraph } 1 \text { of Article } 24 \text {, hunts or catches any wildlife under state priority } \\
\text { conservation in a relevant nature reserve or a no-hunting (or no-fishing) zone or } \\
\text { during a closed hunting (or fishing) season, hunts, catches, or kills any wildlife } \\
\text { under state priority conservation without a special hunting or catching permit or } \\
\text { against the requirements of a special hunting or catching permit, or hunts or } \\
\text { catches any wildlife under state priority conservation with a prohibited tool or by } \\
\text { a prohibited means shall be fined not less than two nor more than ten times the } \\
\text { value of the catch or if there is no catch, be fined not less than } 10,000 \text { yuan nor } \\
\text { more than } 50,000 \text { yuan by the competent department of wildlife conservation of } \\
\text { the people's government at or above the county level, the oceanic law } \\
\text { enforcement department, or the administrative authority of the relevant reserve } \\
\text { according to the division of their functions, with the catch, the hunting or } \\
\text { catching tool, and all illegal income confiscated and the special hunting or } \\
\text { catching permit revoked; and if the violation is criminally punishable, the } \\
\text { offender shall be held criminally liable in accordance with the law. }\end{array}$ \\
\hline \multirow{2}{*}{$\begin{array}{l}\text { Law on the Wild } \\
\text { Plants Protection of } \\
\text { the People's Republic } \\
\text { of China [30] }\end{array}$} & Article 2 & $\begin{array}{l}\text { (...) As regards the protection of medicinal wild plants and wild plants within } \\
\text { urban gardens, nature reserves and scenic spots, other relevant laws and } \\
\text { regulations shall be also applied. }\end{array}$ \\
\hline & Article 11 & $\begin{array}{l}\text { Districts with a natural concentrated distribution of species of wild plants under } \\
\text { special state or local protection shall be designated as nature reserves in } \\
\text { accordance with relevant laws and regulations; }(\ldots) \text {. }\end{array}$ \\
\hline \multicolumn{3}{|r|}{ Laws on Natural Resources } \\
\hline $\begin{array}{l}\text { Forest Law of the } \\
\text { People's Republic of } \\
\text { China [31] }\end{array}$ & Article 24 & $\begin{array}{l}\text { (... ) Serious protection should be given to rare and precious trees outside } \\
\text { nature reserves and plant resources with special value in forest regions; it is } \\
\text { forbidden to cut or collect any plants resources without the approval of the } \\
\text { competent department of forestry of the provinces, autonomous regions and } \\
\text { municipalities directly under the Central Government. }\end{array}$ \\
\hline $\begin{array}{l}\text { Mineral Resources } \\
\text { Law of the People's } \\
\text { Republic of } \\
\text { China [32] }\end{array}$ & Article 20 & $\begin{array}{l}\text { Unless approved by the competent departments authorized by the State Council, } \\
\text { no one may mine mineral resources in the following places: ... (5) nature } \\
\text { reserves and important scenic spots designated by the State, major sites of } \\
\text { immovable historical relics and places of historical interest and scenic beauty that } \\
\text { are under State protection; and (6) other areas where mineral mining is } \\
\text { prohibited by the State. }\end{array}$ \\
\hline
\end{tabular}


Table 2. Cont.

\begin{tabular}{|c|c|c|}
\hline Law & Article No. & Content \\
\hline & & Law on the Special Marine Protected Areas \\
\hline \multirow{4}{*}{$\begin{array}{l}\text { Management } \\
\text { Measures on the } \\
\text { Special Marine } \\
\text { Protected Areas [33] }\end{array}$} & Article 13 & $\begin{array}{l}\text { (...) Before submitting the approval of establishing special marine protected } \\
\text { areas, the authority who submits to the approval shall inform the public and let } \\
\text { the public give some suggestions and comments. }\end{array}$ \\
\hline & Article 17 & $\begin{array}{l}\text { After establishing special marine protected areas, the management authority } \\
\text { shall build some landmarks and signs in some appropriate places according to } \\
\text { their boundaries, the authority also shall publish management rules, measures } \\
\text { and other relevant information on special marine protected areas. }\end{array}$ \\
\hline & Article 28 & $\begin{array}{l}\text { The administrative agency of marine special protected areas shall organize units } \\
\text { and individuals within the areas to participate in the construction and } \\
\text { management of marine special protected areas, cooperate local communities to } \\
\text { participate in the co-management and protection of marine special protected } \\
\text { areas, and jointly formulate plans for cooperative projects, community } \\
\text { development plans, general plans and management plans within the areas. }\end{array}$ \\
\hline & Article 46 & $\begin{array}{l}(\ldots) \text { the authority and the enterprises who explore the special marine protected } \\
\text { areas shall sign a franchise agreement that the income should be devoted to } \\
\text { conserve protected areas and give the compensation to rights holders }(\ldots)\end{array}$ \\
\hline \multicolumn{3}{|r|}{ Laws on Preventing Pollution } \\
\hline $\begin{array}{l}\text { Regulations of the } \\
\text { People's Republic of } \\
\text { China on the } \\
\text { Prevention of } \\
\text { Pollution Damage to } \\
\text { the Marine } \\
\text { Environment by } \\
\text { Land-sourced } \\
\text { Pollution [34] }\end{array}$ & Article 8 & $\begin{array}{l}\text { No organization or individual may establish outlets for discharging sewage } \\
\text { within special marine reserves, marine nature reserves, seashore scenic and } \\
\text { tourist areas, salt works reserves, bathing beaches, important fishing areas and } \\
\text { other areas which need special protection. Those outlets already established } \\
\text { within these areas stipulated in the preceding paragraph, where the discharge of } \\
\text { pollutants is in excess of the national or local discharge standards, shall be } \\
\text { improved within a prescribed period of time. }\end{array}$ \\
\hline $\begin{array}{l}\text { Law of the People's } \\
\text { Republic of China on } \\
\text { Prevention of } \\
\text { Environmental } \\
\text { Pollution Caused by } \\
\text { Solid Waste [35] }\end{array}$ & Article 22 & $\begin{array}{l}\text { It shall be forbidden to construct facilities or sites for the centralized storage and } \\
\text { disposal of industrial solid waste or burial site for residential refuse in nature } \\
\text { reserves, scenic spots, historic sites, drinking water sources, and other places of } \\
\text { special protection designated by the State Council and the people's governments } \\
\text { at the provincial, municipal or autonomous regional levels. }\end{array}$ \\
\hline $\begin{array}{l}\text { Law of the People's } \\
\text { Republic of China on } \\
\text { Prevention and } \\
\text { Control of } \\
\text { Desertification [36] }\end{array}$ & Article 22 & $\begin{array}{l}\text { (...) The local people's government at or above the county level shall make } \\
\text { plans to help the farmers and herdsmen living in the enclosed and forbidden } \\
\text { reserves of desertified land move out of the areas and settle down appropriately. } \\
\text { With regards to production and everyday life of the farmers and herdsmen still } \\
\text { living in the enclosed and forbidden reserves of desertified land, the authority } \\
\text { there shall make proper arrangements for them. Without approval of the State } \\
\text { Council or the authority designated by the State Council, no railways, highways, } \\
\text { etc. may be constructed in enclosed and forbidden reserves of desertified land. }\end{array}$ \\
\hline
\end{tabular}

\subsection{Policy Instruments}

\subsubsection{The Initiative Period: From 1991 Till 2010}

Besides the above-mentioned laws and regulations, some important policy instruments are regarded as relevant guidelines for protected areas management in China. For instance, in 1991, the former State Environmental Protection Administration issued the National 8th Five-Year Plan and Ten-Year Plan on the Protection of Nature Reserve and Species [37]. This was the first specific plan for protected areas. To update this plan, the "Outline of the Development Plan for Nature Reserves in China (1996-2010)" [38] was approved by the State Council in November 1997. The Outline addressed some major problems in protected areas management, including the limited number and surface of protected areas, over-development within protected areas, a shortage of funding, the deficiency of a national development plan and a lack of professionalism in the management of protected areas. In December 2001, the State Forestry Administration (SFA) implemented the Wildlife Conservation and Nature Reserve Construction Project [39], which aims to establish 2500 protected areas covering 172.8 million 
ha (18\% of China's land area) by 2050 [40]. This provides guidance for constructing and managing protected areas, especially for the protected areas with wildlife. The "National Developmental Program on Forest Protected Areas (2006-2030)" [41] provides an important guideline for managing forest protected areas. The "Strategy and Action Plan for Biodiversity Preservation in China (2011-2030)" [42] points out four basic principles for biodiversity conservation, namely conservation priority, sustainable utilization, public participation and benefit-sharing. It also clarifies ten prior fields and thirty actions. The ten prior fields are shown in the Table 3 below.

Table 3. Ref. [42]: Ten prior fields in the "Strategy and Action Plan for Biodiversity Preservation in China (2011-2030)".

\begin{tabular}{|c|c|}
\hline Prior Fields No. & Contents \\
\hline Prior Fields 1 & To improve the policy and legal system for biodiversity conservation and sustainable utilization \\
\hline Prior Fields 2 & To integrate biodiversity conservation into sectoral and regional planning to promote sustainable use \\
\hline Prior Fields 3 & To carry out biodiversity survey, assessment and monitoring \\
\hline Prior Fields 4 & To strengthen in-situ protection for biodiversity \\
\hline Prior Fields 5 & To scientifically adopt ex-situ protection for biodiversity \\
\hline Prior Fields 6 & $\begin{array}{c}\text { To promote rational utilization and benefit sharing of biological genetic resources and the related } \\
\text { traditional knowledge }\end{array}$ \\
\hline Prior Fields 7 & To strengthen the safety management for invasive alien species and genetically modified organisms \\
\hline Prior Fields 8 & To enhance our capacity to respond to climate change \\
\hline Prior Fields 9 & To strengthen scientific research and talent training in the field of biodiversity \\
\hline Prior Fields 10 & To establish public participation mechanisms and partnerships for biodiversity conservation \\
\hline
\end{tabular}

Among these prior fields and actions, pioneer field 1 and actions 4 and 29 are closely relevant for protected areas management. The first pioneer field includes completely reviewing the laws and regulations to solve the conflicts regarding them, researching the laws and regulations on protected areas management and strengthening the implementation system for laws and regulations. Action 4 is to formally manage protected areas and to improve the quality of management, including: drawing up an all-aspects plan for designation and management; regularly evaluating the plan's implementation; exploring the different co-management models for different protected areas; experimenting in the selected areas; and popularizing the experimentation. Action 29 indicates that a broad public participation mechanism should be established, including improving the effective public participation system, concerning hearings and seminars and establishing a public and media supervision mechanism to guarantee the implementation of relevant policy [9] (pp. 143-164).

In addition, the "Notification on Well Managing Protected Areas" was issued by the General Office of the State Council in December 2010 [43]. Ganjie Li, the then deputy Minister of the Environmental Protection Department, said that the State Council proposed the Notification based on several reasons. Among these reasons are the facts that tougher protection implementation is needed, the production and life of local population have been affected and the conflicts regarding protected areas management and the local communities are becoming serious. Secondly, there is a need to establish a co-management mechanism with local people. The participation of local people in protected areas management can not only strengthen the power of the protection, but also can increase their income [44].

\subsubsection{The Rapid Development Period: From 2011 Till 2020}

Notably, the "Decisions of the CPC Central Committee on Several Major Issues Concerning Comprehensively Deepening Reform" [45] proposed that it is necessary to establish a national park system. In January 2015, 13 Ministries, including the National Development and Reform Commission, issued the "Notification on the Pilot Program of Establishing the National Park System" [46]. This notification addresses that "according to the establishment level and protection objectives, 
the overlapping and fragmented areas of various protected areas in the pilot areas shall be cleaned up, standardized and integrated." On 18 May 2015, the State Council approved and forwarded the "Opinions of the National Development and Reform Commission on the Key Work of Deepening Economic Restructuring in 2015". The opinions pointed out that it is necessary to launch national park system pilot programs in 9 provinces. On the same day, 13 Ministries jointly issued the "Pilot Program for Establishing a National Park System".

In this context, some important policies were released. For instance, the "General Plan for Establishing a National Park System" was released by the State Council on 26 September 2017. This general plan asks for 'building a collaborative management mechanism and establishing a regulatory mechanism' and 'establishing a diversified funding guarantee mechanism based on government fiscal investment'. At the same year, the standing committee of the 13th National People's Congress included the national park law in its legislative plan. However, these are still under discussion.

In March 2018, the central committee of the Communist Party of China (CPC) issued the "Plan to Deepen the Reform of the Party and State Institutions", asking for the establishment of a National Forestry and Grassland Administration managed by the Ministry of Natural Resources. The National Forestry and Grassland Administration is in charge of managing national parks and other protected areas. In order to further comprehensively deepening reform in protected areas management, the "Guidance on Establishing a System of Protected Areas with National Parks as the Main Body" of 2019 [47] (hereinafter the Guidance) was adopted by the sixth meeting of the Central Committee for Comprehensively Deepening Reform on 23 January 2019. According to the Guidance, it is necessary to establish an innovating mechanism for protected areas management and to establish a protected areas management system, with national parks as the main body, supplemented by all types of natural parks [48] (pp. 128-136).

It was expected that the first "National Parks Law" in China would be drafted by the end of 2019 [49]. Recently, 10 national parks system pilot projects were set up in 12 provinces, covering a total area of 0.22 million square kilometers [49].

The above mentioned laws, regulations and policy instruments show that the Chinese government and different departments have issued various laws, regulations and policies for the establishment and management of protected areas and forbidden activities in or near protected areas. The recent laws and regulations also point out that the interests of local people shall be taken into consideration. It was noted that the central government in China has recently tried to take various measures to conserve protected areas and to improve management mechanisms for protected areas. Still, there are several challenges, which will be discussed in the next section.

\section{Discussion: Challenges of Protected Areas Management}

Since the first national park was established in China in 2016, the goal of protected areas management has evolved from 'merely pursuing the speed of the establishment of protected areas' to 'pursuing the efficiency and effectiveness of the management of protected areas' [50]. Several problems related to general protected areas management still exist. These include conflicts of interest among several management authorities for protected areas, the lack of clear guidance for protected areas management, an insufficient budget, the shortage of professional experts, the lack of public participation, the conflict between management behavior and commercial profit behavior and conflicts between protected areas management and local communities. Among these challenges of protected areas management, we identify four main challenges: institutional barriers, incomplete legislation, insufficient public participation and a lack of funding. These challenges will be discussed in more detail below.

\subsection{Institutional Barriers}

The current institutional setting of protected areas management demonstrates irreconcilable problems, such as local protectionism, non-compliance with central regulations at the local level and 
interagency rivalries [51]. Among these problems, there are three main issues. Firstly, the division of powers between the central and local governments and their expenditure responsibilities have not been clearly defined [52]. For example, in some cases management responsibilities are taken by the central government, but the financial means are insufficient. Another example is that the central government had to take responsibilities that belong to local governments, which have failed to carry out their responsibilities [52].

Secondly, there are some conflicts of interest among several management authorities for protected areas. According to Article 7 of the revised "Regulations of the People's Republic of China on Nature Reserves", the people's governments at or above the county level shall strengthen leadership for the work concerning protected areas. In practice, there are problems to appropriately lead the protected areas management. For instance, the Wuyishan protected area spans three cities in Fujian province and one city in Jiangxi province. Although the management authority of this protected area is subordinate to the forestry bureau of Fujian province, there are some management interests' conflicts among these four cities in these two provinces [53]. Due to the fact that one protected area occupies more than one administrative area, these administrative areas are managed by different administrative departments. When the responsibilities for managing protected areas of these administrative departments are not clear, this can seriously affect the efficiency and effectiveness of protected areas management.

Thirdly, when real or perceived conflicts between economic development and the enforcement of environmental laws and regulations arise, economic development usually wins [54]. Very often, nature is sacrificed to pave the road for economic development, for instance rapid urbanization [55], dam infrastructure [56] and the construction of transportation infrastructure. According to the National Report on the Implementation of the Convention of Biodiversity, the former Ministry of Environmental Protection [57] claims that the Chinese government "made every effort to keep railways and highways away from sensitive areas such as nature reserves and took measures to lower their environmental impacts", for instance the Qinghai-Tibet railways [58]. However, suspicion can be raised regarding the effects of the implementation of transportation infrastructure projects at the local level [51].

These institutional barriers are common challenges for protected areas in general. How to solve these barriers is the first key step to sweep away the obstacles for specific barriers for different types of protected areas in China.

\subsection{Incomplete Legislation}

\subsubsection{No Comprehensive Law Covering All Types of Protected Areas}

Protected areas contain national parks, forest parks, scenic spots and other different types of protected areas managed by the different levels of governments in China. The designation of protected areas is diversified and lacks uniformity. There is no comprehensive law that covers all types of designations of protected areas. As introduced above, protected areas management can only get some basic legal support from the revised "Regulations of the PRC. on Nature reserves" and some clauses from related laws and regulations. A general governing concept for protected areas has not been adopted in the legislative framework [51] (p. 204). Protected areas management cannot get a specific legal support from the level of 'law' in the Chinese legislative framework. The current legislative framework is piecemeal and cannot meet the needs of protected areas management [51] (p. 204). In other words, the protected areas management is not effectively regulated under the existing legal framework, leading to the 'paper park syndrome' [51]. This fragmented approach does not work.

Some scholars have argued for the goal of 'one protected area, one enabling act' in 2007, that is, site-specific legislation for protected area units [59]. However, this argument has not been fully put into practice. By the end of 2012, 'local regulations' had been enacted by local people's congresses in 19 provinces and 'enabling legislation' had been adopted in 82 'Scenic and Historic Areas at the national level.' [60] According to the statistics on protected areas in 2013, the number of enabling legislation for individual protected areas stands at approximately 50 [51] (p. 194). According to the 
statistics in 2016, there are more than 200 special management regulations or rules for protected areas in 24 provinces or cities in China [61]. Although the number of special regulations or rules for individual protected areas is increasing, compared with the total number of protected areas, there is still a big gap.

\subsubsection{Challenges after Issuing a Specific Law for National Parks}

A specific law for national parks is a big step forward to achieve a 'one type of protected area, one enabling act'. The first "National Parks Law" in China would have been drafted by the end of 2019 [49], however, it is still under discussion in 2020. The "Guidance" (2019) is regarded as the top-level design of China's protected areas system and a programmatic document to guide the pilot construction of a national parks system to solve the remaining problems of protected areas. Some scholars claim that it is necessary to accelerate the legislative process of the national parks law, to set up the functional positioning, protection objectives and management principles of national parks in the form of laws; it is also urgent to reasonably delineate the responsibilities of the central and local governments, to research and formulate supporting laws and regulations on the franchising of national parks [62] (pp. 123-127). Besides these, it is necessary to clarify the relationship between the future "National Parks Law" and the existing legal system on protected areas, especially the relationship among the future "National Parks Law", the existing "Regulations of the People's Republic of China on Nature Reserves" and the "Regulations of the People's Republic of China on Scenic Spots" [63].

\subsubsection{Other Gaps in the Existing Legislation}

There are also other gaps in the existing legislation on protected areas. Firstly, there is little attention to address degradation in protected areas, in case that protected areas are not well managed. A national protected area will get more financial support from the central government and more benefits from exploitation and tourists. There is a risk that when an area becomes a national protected area, the relevant agencies would pay much attention to exploit the protected area and attract more tourists to make more money and pay less attention to explore all necessary ways to guarantee the effectiveness and efficiency of protected areas management. For instance, in 2018, the special operation of "green shield 2018" protected areas supervision and inspection jointly launched by the Ministry of Ecology and Environment and other departments found that human disturbances, such as mining, breeding and ginseng bases were common in the Hunchun amur tiger national protected area, and the overall protection effect of the protected area was poor [64]. Thus, it is necessary to address degradation and restoration in the relevant laws and regulations. This degradation and restoration mechanism may stimulate the management authorities of protected areas to try their best to effectively manage protected areas.

Secondly, the current legislation on protected areas management does not pay enough attention to public participation and problems in funding use. Thirdly, targeted measures to punish the illegal behavior for inappropriate use of funding for protected areas are necessary in the relevant laws and regulations. These two issues will be discussed in the following sections.

\subsection{Insufficient Public Participation}

\subsubsection{Limitations for Public Participation}

Although China has made some progress in public participation in China [65], compared to some developed counties, there are still large limitations for public participation [1] (pp. 250-255). Firstly, the general public, who is willing to actively join in, do not have enough capacities to participate in environmental issues, especially protected areas management [1] (p. 252). These capacities contain various aspects, for instance, enough skills to learn the characteristics of protected areas and the real challenges in protected areas management, enough abilities to know how to actively participate in the whole process and to know how to express themselves in a formal way or enough knowledge on how to guarantee their legal rights or ask for a legal remedy for any harm or injury they have suffered. 
These capacities cannot easily be acquired in a short time. There is a long way to go for the general public and local people in China to obtain the capacities to participate in protected area management.

Secondly, the organizational form of participation is limited in scale [66] (pp. 20-22). Chinese environmental protection associations, especially environmental NGOs, have limited impact on governments' decision-making [66] (p. 21) [67] (p. 12). Currently, although the number of environmental protection associations in China is more than 3000, many NGOs have official governmental sponsors who guide them through the registration processes and provide political cover and support for their work [68] (p. 1259). Very few of them are initiated by civil environmentalists [9] (pp. 143-164). Environmental NGOs in China can be divided into two general categories: those affiliated with government agencies, namely government organized NGOs (GONGOs), and other private NGOs. Their limited funding and acceptance by the government determine their participation status [9] (pp. 143-164). China needs to develop a rich collection of citizens' groups to respond to the growing environmental crisis, and strongly encourage NGOs to embrace the diversity of citizens groups that care about the environment, thereby allowing them to find their collective voice [68] (pp. 1259-1260).

Thirdly, the process of participation is not comprehensive [67] (p. 12) [69] (p. 124), as public participation is mainly post-supervision. There is little pre-supervision and process supervision [9]. For instance, Article 6 of the "Environmental Protection Law of the People's Republic of China" (1989 version) [70] states that "All units and individuals shall have the obligation to protect the environment, and have the right to report on or file charges against any units or individuals that cause pollution or environmental destruction". The "Decision by the State Council on Several Environmental Protection Issues" [71] also emphasizes that "It should (... ) encourage the public to participate in environmental protection, and inform and disclose the various illegal actions against environmental laws and regulations". It can be seen from these examples that the laws in China concerning public participation emphasize the post-supervision on illegal action to the environment, neglecting pre-supervision and process supervision [72] (p. 62). In practice, after the pollution or environmental destruction have already happened, the public will inform the relevant parties and rely on the government to solve the problems.

Fourth, from the perspective of the contents of participation, the current public participation is feeble, mainly limited to consciousness participation, such as asking for comments from the public, while there is little participation in actual behavior changes [69] (p. 124). The public and environmental NGOs involved in environmental protection activities mainly focus on publicity and education [9] (pp. 143-164). They support environmental protection from the perspectives of consciousness and public opinion, rather than the actual behavior, especially the participation in government's environmental decision-making.

Fifth, public participation is mainly organized by the government, while the system for public participation is insufficient in China [9] (pp. 143-164). To a great extent, the scope and effect of participation is decided by the main administrative department, and people fail to really recognize that environmental protection is also their obligation [73]. For instance, Article 13 from the "Law of the People's Republic of China on Prevention and Control of Pollution from Environmental Noise" (1996) [74] states "the environmental impact statement shall include the comments and suggestions of the units and residents in the place where the construction project is located." However, these provisions are too theoretical, they do not point out when the public can participate, in which way the public can participate and how to guarantee public participation. What is more, even though the "Law of the People's Republic of China on Environmental Impact Assessment" (hereinafter, as EIA Law) explicitly requires public participation in environmental impact assessments, the two most popularly adopted means, namely questionnaire surveys and public meetings, have been criticized as insufficient [75] (pp. 18-32). There are no explicit procedures or guidelines for holding consultation meetings or environmental hearings for the formulation of public opinion [76] (p. 147). Yue PAN, the then deputy director of the former Ministry of Environmental Protection of the People's Republic of China [57], pointed out that according to the first public environmental people's livelihood index, released by 
the China Environmental Culture Promotion Association, only $6.3 \%$ of the public has participated in environmental activities in the last three months in 2006 ; less than $20 \%$ of the public know " 12369 ", which is the free phone line for environmental issues [77]. The essential reason for this is not the low level of public environmental awareness, but the lack of effective mechanisms for the public to access environmental information and to participate in environmental issues [77]. Public opinions, although procedurally significant, remain legally non-binding [76] (p. 147).

\subsubsection{Analysis of the Right to Participation in Protected Areas}

The degree to which local governments adhere to the principles of nature conservation is also questionable [78]. Local governments in China often perceive the development of protected areas as a symbol of administrative achievement and a potential source of tourism income [79] (pp. 599-605). As a result, important decisions such as the zoning and configuration of protected areas are regularly driven by local socio-economic interests rather than by strategic objectives [80] (pp. 39-50). In addition, local communities in developing countries often have limited experiences in public decision-making [78], this being particularly true in a country like China with a long standing tradition of top-down governance. The present legal system for protected areas in China arguably has the disadvantages of decentralization, i.e., design, enforcement and monitoring of the forbidden activities are all left to the government, mainly to the local government which focuses more on economic development than on strategic protected areas conservation objectives, without the advantages of bottom-up approaches, i.e., promotion of stakeholder participation, cooperation and innovation [79] (pp. 599-605). China's experience demonstrates the need for a balance between top-down and bottom-up approaches [79] (pp. 599-605). While methods and procedures for public participation have been established in some new environmental regulations in China, such as the Law on Environmental Impact Assessment of the People's Republic of China [81], they have yet to be incorporated into protected area regulations [79] (pp. 599-605) [82]. Although there are some Articles that refer to the interests of rights holders in protected areas, for instance the " Management Measures on the Special Marine Protected Areas" (Article 46) [83], it does not clearly mention the specific definition of rights and rights holders, how to judge the loss of rights holders and the procedures to deal with possible compensation. Furthermore, insufficient public consultation in protection areas decision-making may potentially escalate into conflicts between local people and protected areas, for instance the conflict between the right to cut down forests of local people and forest protected areas conservation. In such a context, seeking better solutions to solve the conflicts regarding protected areas management and public participation, is not about weakening the role of the State. By contrast, the State needs to play an active role in certain areas, such as building competent and accountable local institutions, ensuring quality standards and establishing statutory procedures for public participation in decision-making [84] (pp. 185-206).

Besides, due to the short history of environmental law research and education in China [85], there is no guarantee that there are enough and adequate staffs with professional qualification for protected areas management. For this reason, the enthusiasm, local knowledge and power from local people and communities and environmental NGOs could be regarded as an irreplaceable role in protected areas management. More importantly, local knowledge and experience from local people and communities could be used to fill knowledge gaps and to develop site-specific management measures tested over time [1] (p. 166).

\subsection{Deficiency of Funding for Protected Areas}

The lack of sufficient funding for protected area management has been a long-lasting problem, that has been identified more than 20 years ago. Already according to an announcement issued by the State Council in 1998, it was estimated that 'at least one-third of the nature reserves have 'three withouts' (without a management agency, without staff and without recurrent funding)' in China [86]. James Harness observed that 'the rapid growth of China's protected areas system during the 1980s was 
not accompanied by a commensurate increase in state financial support for conservation' [87] (p. 917). Most protected areas have to 'fund themselves by themselves' [88] (p. 197).

A study in 2011 supports the notion that the deficiency in funding for protected areas has been gradually alleviated [89] (pp. 296-300). The authors show that the total investment in protected areas at the national level reached 550 USD per $\mathrm{km}^{2}$ in 2009. Compared to 113.1 USD per $\mathrm{km}^{2}$ in 1999, the total investment in protected areas at the national level increased by a factor of 2.3 [89] (p. 298). The report concludes that $65 \%$ of protected areas at the national level received sufficient funding to cover their expenditures [89] (p. 296). This result only refers to protected areas at the national level. The situation of protected areas at the local level might be even worse.

Funding from the central government only accounts for a limited portion of the overall funding structure. A large amount of funding for protected areas is supported by local financing, especially for local protected areas. However, protected areas in different provinces normally receive significantly different amounts of funding from the local government, due to the various levels of economic development in these provinces. For instance, according to a survey conducted in 1998, the Lingdingfutian protected areas at the national level received 2.9 million yuan [90] from Guangdong province, whereas the Maolan protected areas at the national level only received 0.28 million yuan from Guizhou Province [91] (p. 14).

In fact, a rough estimation by the State Environmental Protection Agency shows that during the 2001 to 2010 period, the total funds needed, amounted to approximately 445 million yuan per year [38]. Ma Zhong estimates that 1 billion yuan are needed per year to protect protected areas at the national level, which is 10 times the amount of funding allocated for protected areas [92]. Based on research from the Nature Conservation Legislation Research Group, in order to protect China's important biodiversity and ecosystem services and to guarantee China's ecological safety, China needs 26 billion yuan in protected areas establishment and management [64]. These results differ substantially [92]. However, even if we ambitiously consider the highest amount (i.e., 26 billion yuan), it only accounts for less than $0.21 \%$ of the overall outlay in 2012 [93].

According to statistics in 2019, the central government invests only 600 million yuan annually in 474 national protected areas, with an average of 1.26 million yuan per protected area. The central government spends only 2 million yuan a year on 244 national scenic spots, less than 10,000 yuan per year on average [64]. Obviously, the financial support from the central government alone cannot meet the financial requirement of protected areas establishment and management in China, as mentioned above.

\subsubsection{Limited Financial Sources}

The main financial sources for protected areas management in China normally come from the different levels of government. There are some main problems with the financial resources for protected areas management. Firstly, the financial support cannot meet the daily requirements in protected areas management, such as for staff, equipment and maintenance of visitor centers [94]. The timeliness and adequacy of daily funds are difficult to be ensured. Compared with the requirements in practice, the central financial input is very limited for protected areas management. Also, the investment mechanism of various regions at the local level is often limited to the planning level or is delayed. The actual financial needs of protected areas cannot be met in time.

Secondly, owing to the unsound legal protection mechanism for the funding, it is difficult for local governments to fully explore the possible ways to obtain financial support from NGOs and individuals in protected areas management. Although some relevant policies encourage social capital and public welfare funds to actively participate in the investment of protected areas, the relevant laws and regulations do not pay much attention to this aspect. The potential roles of individuals or NGOs in this field are not fully stimulated.

Thirdly, there is no provision on how funding would be used for protected areas and how to use of this funding can be monitored. Only Article 6 of the revised "Regulations of the People's Republic of 
China on Nature Reserves" (2017) says that "the management organization or the administrative department in nature reserve may accept the donation from NGOs and individuals at home and abroad for the construction and management of nature reserves". However, there is no provision addressing how this donation would be used in protected areas and who would monitor this donation. Also, there is no specific agency to monitor how the funding would be used for protected areas management. Therefore, the donation for protected areas in China is comparatively quite low in the proportion of the whole funding for protected areas.

\subsubsection{Subsidies for Protected Areas}

Article 23.2 of the revised "Regulations of the People's Republic of China on Nature Reserves" (2017) addresses that "the Central government would provide an appropriate subsidy for protected areas management." However, there are no specific standards on how to define 'appropriate'. In this context, the subsidies from the central government for each protected area are unstable [95] (pp. 18-20).

Furthermore, the subsidy from the central government for each protected area in China will be different according to the different classification of the protected area. A national protected area will get a higher subsidy than a local protected area, no matter where the national protected area is located. If the national protected area is located in a richer province, it will get a comparatively higher financial support from the local government. The total amount of funding for this national protected area will be higher than a national protected area located in a poor region, because of lower financial support from the local government. A local protected area gets limited funding for the management [96] (pp. 14-19), especially a local protected area located in a poorer province.

\subsubsection{Problems in the Use of Funding}

There are also some main problems in the use of funding. Firstly, the funding in general for protected areas can be classified into funding for the establishment and funding for the management of the protected areas. The specific standards for the funding for the establishment of protected areas can be found in the "Establishment Standards for Protected Areas Projects" [97]. The standards provide a basic guideline on how to use the funding for the establishment of protected areas. However, the standard for the funding for protected areas management is unclear and the sources of the funding are unstable. Because of these reasons, some protected areas were established, but are not well managed [98].

Secondly, the agency that is in charge of the funding for protected areas management is sometimes unclear. Article 23.1 of the revised "Regulations of the People's Republic of China on Nature Reserves" (2017) points out that "local governments which above the county level arrange the fund for protected areas management." However, some protected areas, especially national protected areas, occupy more than one county in China. The relevant regulations or rules did not pay much attention to this. Therefore, which county is in charge of the funding for protected areas management is uncertain. In these cases, the financial sources of protected areas from the local government are usually very limited.

Thirdly, the funding for protected areas are not well managed and they are not efficiently spent. Due to the unclear powers and responsibilities of different administrative agencies for protected areas management, the input of funds cannot produce an expected output. The malpractice of multiple management has not been effectively solved in the pilot program of national parks and some unnecessary funds on protected areas are spent on various administrative agencies.

Fourthly, the funding from the different levels of governments is inefficiently used, because there is not an appropriate supervision and management mechanism. On the one hand, there is not a reasonable channel for the public to clearly know how the funding was used for a specific protected area; on the other hand, different levels of governments do not have an obligation to timely announce the relevant information according to the relevant laws and regulations. It is quite difficult for the public to monitor the funding used in protected areas management. Besides, the scope of administrative supervision is narrow. Generally, administrative supervision mainly focuses on the 
special funding for the national protected areas in China and pay little attention to the local protected areas. For instance, the "Management Methods on Special Funds Utilization for Protected Areas" (2001) [99] and "Standardization of Construction and Management Guidelines for National Protected Areas" (2009) [100] focus on the management of national protected areas. The funding for local protected areas is limited and there is no supervision mechanism for this funding. There is no guarantee that all the funding for local protected areas are appropriately used.

Finally, there is no effective mechanism to correct or restrain inappropriate behavior in the use of funding. More importantly, there is no independent agency to monitor this behavior in the use of funding, even if there is some indirect provisions on abuse of power in the relevant administrative rules.

\section{Suggestions for Better Protected Areas Management in China}

It has been asserted that "China's problem now is not the absence of environmental laws but the challenge of making them work." [101] (p. 418) Concerning protected areas management, the key issue is to make the existing laws, regulations and policy more detailed and comprehensive in theory and implement them in practice.

\subsection{Improving the Management System by Establishing "One Type of Protected Areas, One Law or Regulation" System}

It is obvious to see that all the protected areas mentioned above cannot be protected and managed in a unified way. It is necessary to improve the management system by "one type of protected area, one law or regulation" and clarify the specific responsibilities of relevant administrative authorities for protected areas management.

Some proposals have been made to improve the management system for protected areas, such as the establishment of an ad hoc department or committee at the central level to unify the conservation authority and the reform of the State Forestry Administration in China by separating its productive and protective functions and merging its protective function with the former Ministry of Environmental Protection [102]. Some protected areas have adopted the institutional structure 'under direct control of governments or departments at the provincial level' and thus have lessened the improper interference from governments at lower levels [103]. An important part of the institutional reform in 2018 was to integrate the management responsibilities of protected areas, scenic spots, natural heritage sites and geoparks scattered among various departments into the national forestry and grassland administration [64]. At the local level, there has been an ongoing effort toward the establishment of ad hoc management agencies at the ground-management level and the strengthening of their authority over integrated management [51] (p. 331).

In this context, on the one hand, it is necessary to accelerate the establishment of unified management and regulatory agencies of various types of protected areas, including national parks [52]. To cope with the problem of interference in agencies by local governments, a plausible solution is to elevate the level that is in charge of 'leading' the management agencies [51] (p. 331). On the other hand, it is necessary to clarify appropriate responsibilities of different management agencies in different levels for different protected areas. According to Article 8 of the "Regulations of the People's Republic of China on Nature Reserves", "The State shall institute a system which combines integrated management with separate departmental management for the management of nature reserves. The competent department of environment protection under the State Council is responsible for the integrated management of the nature reserves throughout the country. The competent departments of forestry, agriculture, geology and mineral resources, water conservancy, and marine affairs and other departments concerned are respectively responsible for relevant nature reserves under their jurisdiction. The people's governments of provinces, autonomous regions and municipalities directly under the Central Government shall, according to the specific condition of the locality, decide on the establishment and the responsibilities of the administrative departments of nature reserves in the people's governments at or above the county level." The key problem is how to further clarify the responsibilities of the departments of forestry, agriculture, geology and mineral 
resources, water conservancy and marine affairs and other departments concerned that are respectively responsible for the relevant protected areas in Article 8.

In practice, many protected areas are faced with the lack of practical legal support in the management process. However, national unified legislation for protected areas merely gives the principle guidance for protected areas management, this cannot meet the specific requirements in practice. The legislative model of "one type of protected area, one law or regulation" is an effective method to solve this problem.

\subsection{Improving the Relevant Legislation}

\subsubsection{Towards a Comprehensive Legislative System for Protected Areas}

As indicated above, the policy and legislative target is to establish a "protected areas management system with national parks as the main body, various protected areas as the basis and other natural parks as a supplement" [47]. In this context, the legislation for protected areas should be a comprehensive and systematic legislative system. The key issue is to consider a protected areas 'law', instead of the existing protected area 'regulation'. The ideal model is a legislative system with a 'basic protected areas law + some specialized protected areas laws or regulations' [104] (pp. 20-23). In the context of the Chinese Constitution, this system would regard the protected areas law as a main body, together with different types of protected areas regulations [104] (pp. 20-23). Ideally, this protected areas law should (1) focus on the common problems and challenges in protected areas establishment and management, (2) confirm the values of protected areas, the aims and principles of the management and (3) clarify who will be the supervising subjects and the rights and duties of various management agencies, basic management guidelines and a basic system for the development and operation of protected areas [105] (pp. 70-73).

Some detailed and specialized issues should be found in some specialized protected areas regulations. The future "National Parks Law" could be regarded as a typical specialized protected areas law. As indicated above, the draft law is still under discussion. An important issue for the future "National Parks Law" is to reclassify and integrate various types of protected areas. For instance, the pilot program of Wuyi Mountain national park in Fujian province occupies the Wuyi Mountain national protected areas, Wuyi Mountain national spot and Jiuqu river upper protection zone; the pilot program of Nanshan national park in Hunan province occupies the former Nanshan national scenic spot, Jintongshan national protected areas, Liangjiang canyon national forest park and Baiyun lake national wetland park. It remains a challenge to solve the potential conflicts among all these former management agencies in the former parks and protected areas.

\subsubsection{Key challenges for a Comprehensive Legislative System on Protected Areas}

Some key challenges must be considered in case a comprehensive legislative system on protected areas would be adopted [104] (pp. 20-23): (1) how to link the "National Parks Law" with the future "Protected Areas Law"; (2) how to deal with the effectiveness of the "National Parks Law" and the future "Protected Areas Law"; (3) how to deal with the management status of different levels of governments in protected areas management; (4) how to balance different interests among different management agencies in different administrative areas; (5) how to clearly define the rights and duties of all the relative parties; (6) how to effectively guarantee the relative parties' legitimate interests; how to establish a coordination system between development and protection; (7) how to establish a departmental coordination system; (8) how to establish a clear legal duty system; (9) how to establish a dispute resolution system. The relevant regulations or laws also need to encourage local people and communities to actively participate in protecting national parks and natural resources in and around national parks by signing cooperative conservation agreements [62] (pp. 123-127). It is also necessary to clarify the legal status and the scope of work of environmental NGOs in all protected 
areas management, especially national parks management, in the relevant law or regulation [106] (pp. 117-122).

Last but not least, according to the report of the 19th national congress of the Communist Party of China, the plan is to accelerate the reform of an ecological civilization system and to build a beautiful China. Therefore, it is necessary to establish 'a natural protected areas system with national parks as the main body', to 'build a land space development and protection system' and to 'improve supporting policies for functional zones' [107] (pp. 81-92). All these measures are part of the 'reform of ecological and environmental supervision system' [107] (pp. 81-92).

If China could provide a comprehensive law for protected areas, it could give a strong and practical legal guarantee for the goal of protecting the authenticity and integrity of ecosystems in protected areas [48] (pp. 128-136). If China could comprehensively improve the existing laws and regulations on protected areas and effectively implement them, biodiversity could be protected and ecological safety could be guaranteed. Only in this way, can the main principle of 'protection priority and restoration in a natural way', which was proposed by the report of the 18th National Congress of the Communist Party of China in 2012, be put into practice by the institutionalization, standardization and procedural arrangement of laws [48] (pp. 128-136).

\subsection{Promoting Public Participation}

\subsubsection{From 'Passive Participation' to 'Active Participation'}

The recent management concerns for protected areas requires greater inclusivity of a broader spectrum of actors and right holders, with growing attention to landscapes and seascapes protected by indigenous peoples, local communities, private owners and other actors which complement conservation areas managed by state agencies [2]. It is necessary to bring environmental democracy into the legislation, especially ensuring the right to information and the right to participation for any parties, including NGOs, in protected areas management [9] (pp. 143-164). Public participation should include pre-planning participation (the public can get the opportunity to participate in the discussions or negotiations before drafting environmental policy or legislation, or preparing construction projects), process participation (the public can participate in the process of implementing the environmental law, regulation or policy or constructing programs), action participation (the public has an awareness of 'protecting the environment by ourselves' and put the awareness into real behavior) and final participation (the public can access the legal system and get a legal remedy). Only through these four types of participation can the public have a holistic and real form of participation. So, it is better to move from 'passive participation' [108] (pp. 297-330) to 'self-mobilization participation' [108] (pp. 297-330) [109] or 'active participation'.

\subsubsection{Some Improvements on Public Participation in the Recent Regulations and Policies}

Some improvements have been made in the relative regulations and policy since 2010. For instance, Article 13 of the "Management Measures on the Special Marine Protected Areas" [33] states that before establishing marine protected areas, the authority shall inform the public and let the public give some suggestions and comments. Article 17 points out to the information issue: it states that after establishing special marine protected areas, the authority shall build some landmarks and signs in some appropriate places according to their boundaries, the authority also shall publish management rules, measures and other relevant information on special marine protected areas.

Another notable example of the improvement is the "Strategy and Action Plan for Biodiversity Preservation in China" (2011-2030) [42], as discussed above under Section 3.4.1.

The former Ministry of Environmental Protection has issued a "Notification on Further Strengthening the Hydropower Construction for Environmental Protection" on 6 January 2012 [110]. It points out that it is forbidden to explore any hydropower resource in any protected area, scenic spot and other areas with special conservation values. When building hydroelectric dams, the right to 
information and right to participation of the public must be guaranteed [9] (pp. 143-164). Furthermore, in the 18th National People's Congress of the Chinese Communist Party in 2012, the former Ministry of Environmental Protection commented on environmental issues, stating that four measures are needed; one of them being to further expand the degree of public participation [111].

Furthermore, the revised "Environmental Protection Law of the People's Republic of China" (2014 version) prescribes public participation as one of five fundamental principles (Article 5). Chapter 5 of this law specifically addresses the issue of information disclosure and public participation [112] (pp. 356-363). However, most articles in Chapter 5 refer to the disclosure of pollution-related information and public participation in the environmental impact assessment of construction projects. They do not pay much attention to local communities' participation in protected areas designation and management.

The "General Plan for Establishing a National Park System" addresses that national parks establishment shall follow the principle of 'government oriented, common participation' [113]. It also calls for local peoples, experts, enterprises and social organizations to actively participate in the whole progress of national parks establishment and management. However, there has not been a substantive national institutionalized common decision-making platform for public participation in protected areas establishment and management. In this context, it is necessary to establish and improve a long-term mechanism for governments, enterprises, social organizations and the public to participate in the protection and management of national parks and other protected areas and to explore a new model for the public to participate in the management of natural resources and ecological protection.

In addition, the provincial governments also made some progress in ensuring the public's rights. For instance, in order to further clarify the boundaries of protected areas and to guarantee the public's right to information and right to participation, the Ethnic and Religious Overseas Foreign Affairs Committee of the Hubei Provincial People's Congress proposed some suggestions to modify the “Hubei Xingdoushan National Nature Reserve Management Regulation in Enshi Tujia and Miao autonomous prefecture" [114]. This regulation also shows a step forward on the public's right for protected areas conservation.

More improvements on public participation are expected in the relative legislation and policies. These improvements could be a good guidance for the realization of public participation.

\subsubsection{Recent Improvements in Practice}

Recently, the Kunming survey and design institution of the National Forest and Grassland Bureau in Yunnan province has established the national park planning and design center. The provincial government in Qinghai province and the Chinese Academy of sciences jointly established the Sanjiangyuan national park research institute of the Chinese Academy of Sciences. The National Development and Reform Commission and Tsinghua University jointly established the National Park Research Institute [62] (pp. 123-127). These examples show that more parties began to devote their contributions towards national parks management and more parties have been empowered to participate in protected areas establishment and management. However, more public participation in practice is necessary.

For public participation in protected areas' establishment and management, the highest priority should be given to ensuring that engagement with local actors is an empowering process and ensuring that representation is effective and just [115] (p. 15). Only through this way, a 'co-construction, co-management, co-sharing' model of protected areas management system would be realized [52].

\subsection{Establishing a Diversified Funding Guarantee System}

\subsubsection{Shortage of Funding for Protected Areas Management}

As indicated above, protected areas establishment and management need a huge amount of money. The central government and different levels of governments in China devote a great contribution to it. 
This is the main financial source for protected areas establishment and management, including the regular budget from local governments, special funds from the central government, project investment and supporting funds from local governments [94]. Another financial source is to make money from (1) operational income, such as franchise revenue; (2) service charge, including catering and transportation services; (3) brand benefits, for instance, the benefits generated by the values of ecological products in national parks [94]. However, there is a risk in making money for protected areas management from these activities in case it means that the relevant agencies would pay much more attention to attracting more tourists and pay less attention to the effectiveness and efficiency of protected areas management.

It is predicted that China's economy will face downward pressures in the next 5-10 years [106] (pp. 117-122). In this context, the shortage of funding may become a major challenge for China's protected areas management in the near future [106] (pp. 117-122). The funding from NGOs could fill in this gap, and some NGOs have a strong willingness to actively participate in the protected areas management [106] (pp. 117-122). Furthermore, most protected areas are located in underdeveloped areas with high development needs [94]. Merely relying on the financial support from the different levels of government cannot meet the requirements of protected areas management. It is necessary to attract more input from various parties and to improve the financing mechanism.

\subsubsection{Establishing a Diversified Financing Mechanism}

While actively striving for the transfer payment from the central government, efforts should be made to establish a diversified financing mechanism that combines the input from different levels of governments, social donation funds and the funds from enterprises, NGOs and individuals [52]. Fortunately, some progress has been made [94]. For instance, Sanjiangyuan national park has established a financing security mechanism through the following four measures: (1) strengthening central financial support for the Sanjiangyuan region; (2) establishing a comprehensive ecological compensation system; (3) strengthening financial support; (4) improving the franchise system. Another good example is Qianjiangyuan national forest park in Zhejiang Province. It has established a funding guarantee mechanism with financial input as the main body and financial support from social input as the auxiliary by the following three measures: (1) establishing a fund ledger system; (2) adopting the management of separation of revenue and expenditure; (3) exploring the forest right system reform model of collective forest right leases [94].

There are two main ways to improve the funding system for protected areas management. One way is 'financial input', this means that it is necessary to increase the government input from the different levels of governments. All the national parks where natural resources are owned by the whole people should be directly funded by the central government [116] (pp. 86-96). Another way is 'diversification' through exploring diversified investment and financing models by multiple channels and through entrusting provincial governments to share the financial pressure on protected area management [116] (pp. 86-96).

As indicated above, the "Guidance" (2019) [47] addresses the fact that establishing a diversified funding guarantee system based on financial input is urgently needed. In order to ensure the protection, operation and management of national parks and other protected areas, all the funds from different levels of government, including the investment in infrastructure from the central government, should be in an overall plan and arrangement. After the pilot system of national parks is completed, based on the pilot conditions, it is necessary to improve the funding guarantee model and to encourage financial and social capital to contribute to the establishment of funds for protected areas management. It is necessary to urgently improve the compensation system for ecological protection and to increase fiscal transfer payments based on the size of protected areas and the effectiveness of their management and protection.

Since the trial launch of the national park system [117] in China in 2015, the relevant departments of the central government have provided 9.126 billion yuan in funding through the existing investment channels within the central budget and special transfer payments from the central government to 
support infrastructure construction, compensation for ecological public welfare forests, and wildlife protection in various national parks [62] (pp. 123-127). Local governments from different levels have increased the funding for the construction of national parks, with the total investment reaching 3.951 billion yuan [62] (pp. 123-127). It is noted that some environmental NGOs, such as the Sanjiangyuan Foundation and China Green Foundation also have raised their contribution in national parks management [118] (pp. 5-11).

Two main revenue channels could be explored. One is to 'increase income' by establishing a multi-channel and multiform capital investment mechanism [94]. Another one is to 'increase efficiency' by optimizing the management structure of protected areas. Firstly, all the natural resources in one protected area could be managed by one agency, so as to realize the unified management and to reduce unnecessary administrative expenses. Secondly, in order to improve the efficiency of fund utilization, a fair supervision mechanism could be established to guarantee an open, transparent and multi-pronged fund operation process [94].

It could be useful to develop innovative financing strategies for protected areas, which recognize payments for ecosystem services, including additional government budget support or direct payments from communities and/or industries which benefit from the services provided [2]. It is necessary to establish a trust funding including government funds and social welfare funds. The trust funding mechanism could monitor the funds from different levels of governments in China to guarantee the independence and efficiency of the funds. This mechanism could also efficiently monitor the funding from enterprises, NGOs, volunteers and the public. In this way, enterprises, NGOs, volunteers and the public could know how their money for protected areas management has been used. They may therefore be willing to contribute more for protected areas management. In this context, it is important to provide legal support for the trust fund and its mechanism and determine how to provide a clear and appropriate legal support for them, for instance, through specific requirements for the registration of the management authority for the trust fund, substantive requirements for the fund and a management and supervision system.

It is also necessary to clarify the duties of the management authority for the trust fund. Besides the general duties, including dealing with the trust affairs for the maximal interest of the particular beneficiary, carefully managing the trust property and being inspected by the public service administration, some specific duties should be included. These specific duties contain providing information on the financial situation, managing and supervising the funding for protected areas management, regularly checking the fund use in the protected areas management, warning and criticizing inappropriate actions in the fund use that violate laws and regulations or informing the relevant authorities to impose administrative punishment or disciplinary punishment. However, these duties will be terminated according to the condition that the management authority for the trust fund is repealed, relieved or any other circumstance provided by law occurs.

\section{Conclusions}

From a historical perspective, some great progress has been made in protected areas conservation and management in China. However, there are four main challenges in protected areas management. These are institutional barriers, incomplete legislation, insufficient public participation and a deficiency of funding. It is necessary and urgent to improve the management system, to improve the relevant legislation, to promote public participation and to establish a diversified funding guarantee system for protected areas management. It is noted that some progress has been made in these aspects. However, further detailed and comprehensive measures should be considered and implemented both in theory and in practice. These additional efforts for protected area management will also be necessary in light of the post-2020 global biodiversity framework that is currently being developed under the Biodiversity Convention. Although no final decisions have been taken, the preparatory documents point to a substantial increase in efforts to protect biodiversity, in which protected areas are a crucial element. The zero draft document not only includes an increase of protected areas or other effective 
area-based conservation measures, but also promotes public participation, and foresees an increase in resources to implement the framework [119]. Whatever the final and exact outcome of the post-2020 global biodiversity framework will be, the whole world community, including China, will have to increase their efforts in order to face the challenges of the ongoing biodiversity crisis.

Author Contributions: Conceptualization, M.H. and A.C.; Methodology, M.H. and A.C.; Writing-Original draft, M.H.; Writing-Review \& editing, M.H. and A.C. All authors have read and agreed to the published version of the manuscript.

Funding: This research was funded by the 'Late Stage Funding Project from Chinese National Funding of Social Sciences' (Grant No. 18FFX044), the 'Postdoctoral Research Foundation of China' (Grant No.: 2016M592359) and the 'Fundamental Research Funds for the Central Universities'. And the APC was funded by the 'Late Stage Funding Project from Chinese National Funding of Social Sciences' (Grant No. 18FFX044).

Acknowledgments: The authors thank three anonymous reviewers for their valuable comments. The study was supported by the 'Late Stage Funding Project from Chinese National Funding of Social Sciences' (Grant No. 18FFX044), the 'Postdoctoral Research Foundation of China' (Grant No.: 2016M592359) and the 'Fundamental Research Funds for the Central Universities'.

Conflicts of Interest: The authors declare no conflict of interest.

\section{References and Notes}

1. He, M. A Human Rights-Based Approach to Conserving Protected Areas in China: Lessons from Europe; Intersentia Publisher: Antwerp, Belgium, 2016; pp. 15-19.

2. Lopoukhine, N.; Crawhall, N.; Dudley, N.; Figgis, P.; Karibuhoye, C.; Laffoley, D.; Miranda Londono, J.; Mackinnon, K.; Sandwith, T. Protected Areas: Providing Natural Solutions to 21st Century Challenges. S.A.P.I.EN.S (Surveys and Perspectives Integrating Environment and Society) [Online], Online Since 10 August 2012. Available online: https://journals.openedition.org/sapiens/1254 (accessed on 30 September 2016).

3. TEEB. The Economics of Ecosystems and Biodiversity in National and International Policy Making; Ten Brink, P., Ed.; Earthscan: London, UK; Washington, DC, USA, 2011. Available online: http://img.teebweb.org/ wp-content/uploads/Study\%20and\%20Reports/Reports/National\%20and\%20International\%20Policy\% 20Making/Executive\%20Summary/National\%20Executive\%20Summary_\%20English.pdf (accessed on 20 August 2019).

4. Mulongoy, K.J.; Gidda, S.B. The value of nature: Ecological, economic, cultural and social benefits of protected areas. Quat. Sci. Rev. 2008, 73, 31-47.

5. Protected Planet. May 2020 Update of the WDPA. Available online: https://www.protectedplanet.net/c/ monthly-updates/2020/may-2020-update-of-the-wdpa (accessed on 10 May 2020).

6. Aichi Biodiversity Targets, UNEP/CBD/COP/DEC/X/2 (29 October 2010).

7. Protected Planet. Aichi Target 11 Dashboard. Available online: https://www.protectedplanet.net/target-11dashboard (accessed on 10 May 2020).

8. Cliquet, A.; Schoukens, H. Convention on Wetlands of International Importance especially as Waterfowl Habitat, Ramsar, 2 February 1971, (1972) 11 ILM 963; Convention Concerning the Protection of the World Cultural and Natural Heritage, Paris, 16 November 1972, (1972) 11 ILM 1358; Convention on Biological Diversity, 5 June 1992, (1992) 31 ILM 818; on international law on protected areas. Terrestrial protected areas. In Biodiversity and Nature Protection Law, Encyclopedia of Environmental Law; Razzaque, J., Morgera, E., Eds.; Edward Elgar Publishing: Cheltenham, UK; Northampton, MA, USA, 2017; pp. 110-122.

9. He, M.; Cliquet, A. Sustainable development through a rights-based approach to conserve protected areas in China. China-EU Law J. 2014, 3, 143-164. [CrossRef]

10. UNEP-WCMC. Protected Area Profile for China from the World Database of Protected Areas. May 2020. Available online: www.protectedplanet.net (accessed on 8 May 2020).

11. CBD. Sixth National Report for the Convention on Biological Diversity. 2018. Available online: https: //chm.cbd.int/database/record/C7B6BC32-C06D-B09C-BFF8-7D265F24DBE6 (accessed on 8 March 2020).

12. People's Daily; People's Daily Publisher: Beijing, China, 2018; p. 14.

13. Protected Areas in China Occupy Nearly 15\% of the Territory. Issued on 13:55; China National Radio: Beijing, China, 2018. 
14. Peng, J. Protected areas system with national parks as the main body: Connotation, composition and construction path. J. Beijing. Univ. (Soc. Sci. Ed.) 2019, 1, 38-44.

15. The “Regulations of the People's Republic of China on Nature Reserves” [中华人民共和国自然保护区条 例] entered into effect on 1 December 1994 and was revised and promulgated on 7 October 2017 by "State Council Order No. 687" of the People's Republic of China.

16. IUCN protected areas management categories classify protected areas according to their management objectives. The categories are recognized by international bodies such as the United Nations and by many national governments as the global standard for defining and recording protected areas and as such are increasingly being incorporated into government legislation. IUCN protected areas management categories are la strict nature reserve, lb wilderness area, II national park, II natural monument or feature, IV habitat/species management area, V protected landscape/seascape, VI protected area with sustainable use of natural resources.

17. Xie, Y. Comparison and reference of nature reserves in China and IUCN protected areas management categories. World Environ. 2016, 5, 53-56.

18. Worboys, G.L.; Lockwood, M.; Kothari, A.; Feary, S.; Pulsford, L. (Eds.) Protected Area Governance and Management; The Australian National University Press: Canberra, Australia, 2015; p. 210.

19. Article 22 of the "Regulations of the People's Republic of China on Nature Reserves" focuses on the duties of the management authorities.

20. The “Constitution of the People's Republic of China" [中华人民共和国宪法] was adopted in 1982 and newly amended on 11 March 2018.

21. The “Environmental Protection Law of the People's Republic of China" [中华人民共和国环境保护法] was promulgated by Order No. 22 of the President of the People's Republic of China on December 26 1989, and entered into effect on the date of promulgation.

22. Article 17 states "The people's governments at various levels shall take measures to conserve areas representing various types of natural ecological systems, areas with a natural distribution of rare and endangered wild animals and plants, areas where major sources of water are conserved, geological structures of major scientific and cultural value, famous areas where karst caves and fossil deposits are distributed, traces of glaciers, volcanos and hot springs, traces of human history, and ancient and precious trees. Damage to the mentioned-above shall be strictly forbidden". Article 17 of the "Environmental Protection Law of the People's Republic of China" (1989 version) is the same as Article 29 of the "Environmental Protection Law of the People's Republic of China" (2014 version). The "Environmental Protection Law of the People's Republic of China" (2014 version) [中华人民共和国环境保护法] was newly modified based on the "Environmental Protection Law of the People's Republic of China" (1989 version) on 24 April 2014 and entered into force on 1 January 2015.

23. The term 'nature reserve' was adopted by most of the relevant regulations; however, at present, more people and NGOs view the term 'protected areas' as more formal and meaningful. For instance, the Nature Conservation Legislation Research Group has argued to replace the term 'nature reserve' with 'protected areas'. This group was organized by Yan Xie from the Institute of Zoology in the Chinese Academy of Sciences and consisted of more than fifty experts in law, biology and other relevant aspects from universities, NGOs, local governments and so on. This paper adopts the more popular term 'protected areas', but when it refers to legal documents, it adopts 'nature reserve' to keep consistent with their translation.

24. Article 18 of the "Environmental Protection Law of the People's Republic of China" (1989 version) does not exist in the "Environmental Protection Law of the People's Republic of China" (2014 version). The “Environmental Protection Law of the People's Republic of China" (2014 version) [中华人民共和国环 境保护法] was newly modified based on the “Environmental Protection Law of the People's Republic of China" (1989 version) on 24 April 2014 and entered into force on 1 January 2015. 
25. Article 19 of the “Environmental Protection Law of the People's Republic of China" (1989 version) [中华 人民共和国环境保护法] is similar with Article 30 of the “Environmental Protection Law of the People's Republic of China" (2014 version). Article 30 says "Exploitation and utilization of natural resources shall be developed in a rational way that conserves biological diversity and safeguards ecological security. Ecological protection and restoration programs shall be developed in accordance with laws and be implemented. For introduction of exotic species as well as the research, development and utilization of biotechnology, effective measures shall be taken to prevent destruction of biodiversity." The "Environmental Protection Law of the People's Republic of China" (2014 version) [中华人民共和国环境保护法] was newly modified based on the "Environmental Protection Law of the People's Republic of China" (1989 version) on 24 April 2014 and entered into force on 1 January 2015.

26. Regarding the hierarchy of legislative documents, generally speaking, there are six categories, namely law (法 律), administrative regulation (行政法规), local regulation (地方性法规), autonomous regulation and separate regulation (自治条例和单行条例), department rule (部门规章) and local government rule (地方政府规章). The "Law" refers to the one enacted by the National People's Congress (NPC) or its standing Committee.

27. Article 5 of the “Regulations of the People's Republic of China on Nature Reserves" [中华人民共和国自然保 护区条例].

28. Article 32 and Article 33 of the “Regulations of the People's Republic of China on Nature Reserves" [中华人 民共和国自然保护区条例].

29. The “Law on the Wildlife Protection of the People's Republic of China" [中华人民共和国野生动物保护法] was issued on 8 November 1988 and revised on 26 October 2018.

30. The “Law on the Wild Plants Protection of the People's Republic of China” [中华人民共和国野生植物保护法] was issued 30 September 1996 and entered into practice on 1 January 1997. It was revised on 7 October 2017.

31. The “Forest Law of the People' Republic of China" [中华人民共和国森林法] was adopted in 1984 and amended on 27 August 2009.

32. The “Mineral Resources Law of the People's Republic of China" [中华人民共和国矿产资源法] was adopted in 1989 and amended on 27 August 2009.

33. The “Management Measures on the Special Marine Protected Areas" [海洋特别保护区管理办法] was issued by the State Oceanic Administration of the People's Republic of China on 31August 2010. Although it is called and translated as "management measures", it is a regulation for special marine protected areas in China.

34. The "Regulations of the People's Republic of China on the Prevention of Pollution Damage to the Marine Environment by Land-sourced Pollution” [中华人民共和国防治陆源污染物污染损害海洋环境管理条例] entered into effect on 1 August 1990.

35. The "Law of the People's Republic of China on Prevention of Environmental Pollution Caused by Solid Waste” [中华人民共和国固体废物污染环境防治法] was issued in 1995 and was amended on 25 June 2019.

36. The “Law of the People's Republic of China on Prevention and Control of Desertification" [中华人民共和国 防沙治沙法] entered into effect on 31 August 2001 and was revised on 26 October 2018.

37. SEPA, National 8th Five-Year Plan and Ten-Year Plan on Protection of Nature Reserve and Species [全国自然 保护区和物种保护八五计划和十年规划], 1991.

38. SEPA, Outline of the Development Plan for Nature Reserves in China (1996-2010) [中国自然保护区发展规划 纲要（1996-2010年）], 1997.

39. The “National Wildlife Conservation and Natural Reserve Construction General Plan" [全国野生动植物保护 及自然保护区建设工程总体规划] Was Issued in 2001. Available online: http://www.beinet.net.cn/zcfg/gh/ qggh/200802/P020080423597945791148.pdf (accessed on 1 December 2019).

40. Xu, J.C.; Melick, D. Towards Community-Driven Conservation in Southwest China: Reconciling State and Local Perceptions; Working Paper No. 52; ICRAF (International Center for Research in AgroForestry): Nairobi, Kenya, 2018; p. 3.

41. The “National Developmental Program on Forest Protected Areas (2006-2030)” [全国林业自然保护区发展规 划（2006-2030年）] was issued by the State Forestry Bureau in 2006.

42. The “Strategy and Action Plan for Biodiversity Preservation in China (2011-2030)" [中国生物多样性保护战 略与行动计划(2011-2030)] was issued by the Chinese Environmental Protection Bureau on 17 September 2010. Although it is only a legal document from the Chinese Environmental Protection Bureau, it is regarded as guidelines for solving the relevant issues in China. 
43. The “Notification on Well Managing Protected Areas from the General Office of the State Council” [国务院 办公厅关于做好自然保护区管理有关工作的通知] was issued in December 2010. Although it is called and translated as "Notification", it is regarded as guidelines for implementing the relevant regulation and solving the relevant issues on protected areas in China.

44. China Environmental Newspaper. Strengthen Protected Areas Management and Promote Ecological Civilization. 2010. Available online: http://www.clapv.org/weiquanwenxian_content.asp?id=175 (accessed on 8 October 2018). (In Chinese)

45. The “Decisions of the CPC Central Committee on Several Major Issues Concerning Comprehensively Deepening Reform" [《中共中央关于全面深化改革若干重大问题的决定》] was published during the third plenary session of the 18th central committee on 15 November 2013.

46. The “Notification on the Pilot Program of Establishing the National Park System" [《关于印发建立国家公园 体制试点方案的通知》] was issued by the National Development and Reform Commission and other 12 Ministries in January 2015.

47. Xinhua News(新华社). The General Office of the CPC Central Committee and the General Office of the State Council issued “Guidance on Establishing a System of Protected Areas with National Parks as the Main Body" [中共中央办公厅国务院办公厅印发《关于建立以国家公园为主体的自然保护地体系的指导意见》], 26 June 2019.

48. Lv, Z.M. Some thoughts on the legislative system for protected areas with national parks as the main body. Biodiversity 2019, 27, 128-136. (In Chinese)

49. Yang, W.L. A Draft of China's First National Parks Law Will Be Issued by THE End of This Year; China Daily: BeiJing, China, 2019. Available online: http://www.chinadaily.com.cn (accessed on 9 July 2019). (In Chinese)

50. OFweek Net. How Should China's Nature Reserves Be Reformed. Shenzhen. 4 November 2016. Available online: https://ecep.ofweek.com/2016-11/ART-93000-8610-30062481.html (accessed on 25 May 2018).

51. Ma, Y. Resolving Conflicts between Conservation and Recreation in Protected Areas: A Comparative Legal Analysis of the United States and China. Ph.D. Thesis, Dissertation in Erasmus School of Law, Erasmus University Rotterdam, Rotterdam, The Netherlands, 2015.

52. Zhang, H.Y. Thoughts and Suggestions on Protected Areas Establishment in the New Era. Qinhai Daily. 12 January 2018. Available online: http://bhq.papc.cn/sf_2E55FACFBE634AB69B8F7ADC42117FBF_262_ isenlinzx.html (accessed on 28 June 2019).

53. Chen, J.K. Four Challenges in Biodiversity Conservation in China. In Proceedings of the Mainstreaming and Marketization of Biodiversity International Conference, Rome, Italy, 9 July 2016. Available online: http://finance.sina.com.cn/roll/2016-07-09/doc-ifxtwchx8368378.shtml (accessed on 15 August 2018).

54. McElwee, C. Environmental Law in China: Mitigating Risk and Ensuring Compliance; Oxford University Press: New York, NY, USA, 2011; p. 6.

55. For example, in 2012, an investment company was expected to spend up to 20 billion yuan to flatten 700 mountains in Lanzhou in the Gansu Province, which is one of China's most chronically water-scarce cities, to build a new metropolis on the outskirts of the city.

56. For example, in 2014, the illegal construction of a dam and hydropower station in a nationally designated poor country in the Shaanxi Province was publicized. This project was not based on an EIA or on the approval procedures from higher authorities. The planned inundated area covers the territory of a national wetland park inhabited by quite a few endangered species. The primary purpose of this project is not to generate electricity but to create human-made and dam-based scenery to facilitate the creation of a 'waterscape city' and the construction of water-based recreational facilities. See detailed information from Chen, X.W. A National Designated Poor Country in Shaanxi Province Spent Millions of Dollars to Build a Hydropower Station for Creating Human-Made and Dam-Based Scenery. Oriental Morning Post. 8 May 2014. Available online: http://news.163.com/14/0508/08/9RN89R4800014AED.html (accessed on 19 May 2019).

57. The Ministry of Environmental Protection was replaced by the Ministry of Ecology and Environment of the People's Republic of China according to the "Institutional Reform Plan for the State Council" approved by the 13th session of the National People's Congress Conference in March 2018.

58. Ministry of Environmental Protection, PRC. China's Fourth National Report on the Implementation of the Convention on Biological Diversity; China Environmental Science Press: Beijing, China, 2009; p. 58.

59. Yan, S.P.; Luo, Y. The theoretical analysis on the legislative model of "One Reserve, One Enabling Act" in nature reserves at the national level. World For. Res. 2007, 20, 68-72. (In Chinese) 
60. MoHURD. Bulletin of the Development of Scenic and Historic Areas in China (1982-2012). Beijing, China, 2012; pp. 3-4. Available online: http://www.mohrd.gov.cn/zxydt/w02012120419937414971793750.doc (accessed on 5 April 2019). (In Chinese)

61. The State Council. "Report of the State Council on the Construction and Management of Protected Areas" [《国务院关于自然保护区建设和管理工作情况的报告》] was issued on 30 June 2016 and implemented on 30 June 2016.

62. Tang, F.L.; Yan, Y.; Liu, W.G. Construction Progress of National Parks in China. Biodivers. Sci. 2019, 27, 123-127.

63. The “Regulations of the People's Republic of China on Scenic Spot” [中华人民共和国风景名胜区管理条例] was issued on 6 September 2006 by the State Council and entered into practice on 1 December 2006.

64. China Business Network (CBN). The Shortage of Funds for Protected Areas in China Became Worse. Shanghai. 3 March 2019. Available online: http://finance.eastmoney.com/a/201903031057966427.html (accessed on 12 April 2019).

65. Hu, X.L. Research on Public Participation in Environmental Decision-Making in the Internet+ Era; Science Press: Beijing, China, 2019. (In Chinese)

66. Wang, C. Study on Legal System for Public Participation in Promoting Ecological Progress. Master's Thesis, Environment and Resources Protection Law of Central South University of Forestry and Technology, Changsha, China, 2013.

67. Wu, Y.; Tian, B. Improvement of public participation system in the east dongting lake nature reserve. J. Wuling 2012, 37, 12. (In Chinese)

68. Zhang, K.M.; Wen, Z.G. Review and challenges of politicizes of environmental protection and sustainable development in China. J. Environ. Manag. 2008, 3, 1259-1260.

69. Zeng, C.L. Research on legal system of right protection of residents of nature reserves in China. J. Dalian Univ. Technol. (Soc. Sci.) 2012, 33, 124.

70. Article 6 of the "Environmental Protection Law of the People's Republic of China" (1989 version) is similar with Article 6 of the "Environmental Protection Law of the People's Republic of China" (2014 version). Article 6 says "All units and individuals shall have the obligation to protect the environment. Local people's governments at various levels shall be responsible for the environmental quality within areas under their jurisdiction. Enterprises, public institutions and any other producers/business operators shall prevent and reduce environmental pollution and ecological destruction, and shall bear the liability for their damage caused by them in accordance with the law. Citizens shall enhance environmental protection awareness, adopt low-carbon and energy-saving lifestyle, and conscientiously fulfill the obligation of environmental protection." The "Environmental Protection Law of the People's Republic of China" (2014 version) [中华人民共和国环境保护法] was newly modified based on the “Environmental Protection Law of the People's Republic of China" (1989 version) on 24 April 2014 and entered into force on 1 January 2015.

71. The “Decision by the State Council on Several Issues Concerning Environmental Protection" [国务院关于环 境保护若干问题的决定] was issued on 3 August 1996. Although it is named as a 'decision', it is regarded as an important guideline for legislation and policy on environmental protection issues.

72. Li, Y.F. The legal system for the public participation and environmental protection. Zhejiang Soc. Sci. 2004, 2,62 .

73. Wang, H. Public Participation in Environmental Management from the Perspective of China. Discussion Papers in Social Responsibility. 2009. Available online: www.socialresponsibility.biz (accessed on 8 August 2012).

74. The "Law of the People's Republic of China on Prevention and Control of Pollution from Environmental Noise" [中华人民共和国噪声污染防治法] Was Issued on 29 October 1996 and Entered into Effect on 1 March 1997. Available online: http://www.lawinfochina.com/display.aspx?lib=law\&id=544 (accessed on 9 August 2012).

75. Wu, G. China in 2010: Dilemmas of "scientific development". Asian Surv. 2010, 51, 18-32. [CrossRef]

76. Du, Q. Public participation and the challenges of environmental justice in China. In Environmental Law and Justice in Context; Ebbesson, J., Okowa, P., Eds.; Cambridge University Press: Cambridge, UK, 2009; p. 147.

77. People's Net. The First "Measures on Public Participation in Environmental Issues was Issued, it Strengthens Democracy in Decision-Making". Beijing, China, 22 February 2006. Available online: http://env.people.com. cn/GB/1072/4130691.html (accessed on 10 October 2012). 
78. Ribot, J.C. Democratic Decentralization of Natural Resources: Institutionalizing Popular Participation; World Resource Institute: Washington, DC, USA, 2002.

79. Qiu, W.; Wang, B.; Jones, P.J.S.; Axmacher, J.C. Challenges in developing China's marine protected areas system. Mar. Policy 2009, 33, 599-605. [CrossRef]

80. Jim, C.Y.; Xu, S.S.W. Recent protected-area designation in China: An evaluation of administrative and statutory procedures. Geogr. J. 2004, 170, 39-50. [CrossRef]

81. The “Law on Environmental Impact Assessment of the People's Republic of China” [中华人民共和国 环境影响评价法] Was Adopted in 2012 and Entered into Effect on 1 September 2003. Available online: http://www.people.com.cn/GB/shehui/212/3572/3574/20021029/853043.html (accessed on 4 May 2012).

82. Pengpai News. Five Hundred Green Peacocks Shut Down a Billion Hydropower pRojects? Both Sides of the Case Appeal, Environmental Impact Assessment Left Hidden Dangers. Shanghai. 8 May 2020. Available online: https://www.sohu.com/a/393832963_260616?spm=smpc.home.top-news2.6.1588943004583s0X6bqd\& _f $\mathrm{f}=$ index_news_5 (accessed on 9 May 2020).

83. Article 46 of the “Management Measures on the Special Marine Protected Areas" [海洋特别保护区管理办法] points out that " (...) the authority and the enterprise who explore the special marine protected areas shall sign a franchise agreement that the income should be devoted to conserve protected areas and give the compensation to rights holders. Due to accidents and emergencies in the special marine protected areas, any units and individuals that cause pollution and damage to the special marine protected areas must take timely measures to reduce or eliminate the impact on the ecology and resources of the special marine protected areas and restore the damaged marine landscape".

84. Bardhan, P. Decentralization of governance and development. J. Econ. Perspect. 2002, 16, 185-206. [CrossRef]

85. In the late 1970s, there was an urgent need to draft China's first environmental protection law(Trial), some legal scholars from Peking University and Chinese Academy of Social Sciences began to research environmental laws. In the early 1980s, Chinese Universities began to offer undergraduate courses on environmental laws. In the early 1990s, the academic degree committee of the State Council began to approve the granting of doctoral degrees in environmental law in Chinese Universities. See more details: Wang, J. The Chinese phenomenon of environmental law: Origin and future. Tsinghua Univ. Law J. 2018, 12, 24-35.

86. State Council, Announcement of the State Council on Further Strengthening the Management of Nature Reserves [国务院办公厅关于进一步加强自然保护区管理工作的通知], Guobanfa No. 111, 1998.

87. Harkness, J. Recent trends in forestry and conservation of biodiversity in China. China Q. (Spec. Issue China's Environ.) 1998, 156, 917. [CrossRef]

88. Zou, K.Y. Management of marine nature reserves in China: A legal perspective. J. Int. Wildl. Law Policy 2003, $6,197$.

89. Li, Y.B.; Li, W.; Zhang, C.; Fan, M. Current status and recent trends in financing China's nature reserves. Biol. Conserv. 2013, 158, 296-300. [CrossRef]

90. Chinese Yuan, Ren(人) Min(民) Bi(币), Chinese Currency.

91. Xu, H.G. Discussion on the funding policy of protected areas in China. Rural Ecol. Environ. 2001, 17, 14.

92. Zhang, K. Report reveals that 26 billion yuan is needed per year to defend the bottom line of ecological safety. First Financial Daily. 9 November 2012. Available online: http:/finacne.qq.com/a/20121109/000350.htm (accessed on 16 May 2018).

93. In recent years, the percentage of the NPS budget in terms of the federal outlay is between around $0.08 \%$ and $0.1 \%$. In China, the estimation of 27 billion covers every aspect of ecological protection in which PA funding only accounts for a very limited part. The overall outlay in 2012 was 125, 71 billion yuan in China. See Ministry of Finance, Financial Revenue and Expenditure in 2012. Available online: http://gks.mof.gov.cn/zhengfuxinxi-/tongjishuju/201301/t20130122_729462.html (accessed on 20 May 2018).

94. Sohu News. How to Obtain Stable and Reasonable Financial Security? On the Fund Guarantee Mechanism of National Parks in China. 24 October 2018. Available online: https://www.sohu.com/a/271054616_168681 (accessed on 12 April 2019).

95. Tao, S.M. Prospects for Protected Areas: From the Perspective of Historical Mission and Strategic for Survival; Science Press: Beijing, China, 2013; pp. 18-20.

96. Lin, S. Improve the law on the fund mechanism for protected areas in China. Xi'an Build. Univ. Sci. Technol. J. (Soc. Sci. Ed.) 2012, 6, 14-19. 
97. The "Establishment Standards for Protected Areas Projects" was formulated by the forestry and grass bureau, jointly managed by the ministry of housing and urban rural development and the National Development and Reform Commission. It entered into practice on 1 December 2018.

98. Wang, Q.D. Legal research on social charge for natural resources management in protected areas. Jurist 2008, 3, 72-80.

99. The “Management Methods on Special Funds Utilization for Protected Areas" (2001) [自然 保护区专项资金使用管理办法] was issued by the Ministry of Finance on 5 December 2001. Available online: http://www.mof.gov.cn/zhengwuxinxi/caizhengwengao/caizhengbuwengao2002/ caizhengbuwengao20021/200805/t20080519_21042.html (accessed on 2 September 2018).

100. The "Standardization of Construction and Management Guidelines for National Protected Areas" (2009) [国家级自然保护区规范化建设和管理导则 (试行) ] was issued on 13 August 2009. Available online: http://www.zhb.gov.cn/gkml/hbb/bh/201004/t20100409_187994.htm (accessed on 3 September 2018).

101. Dan, G.; Song, Y.Q. Making central-local relations work: Comparing America and China environmental governance systems. Front. Environ. Sci. Eng. 2007, 4, 418.

102. Prof. Cai Shouqiu and Prof. Luo Ji hold different opinions on how to re-allocate the productive function of the SFA on the panel discussion during the Annual Conference of the Environmental and Nature Resource Law Society of 2014, held on 21-22 August in Guangzhou, China. Prof. Cai proposed that it is necessary to establish a state-owned enterprise that is responsible for timber production and Prof. Luo proposed for privatization of timber rights in China.

103. For example, Wuyishan Protected Areas at the National Level is under the direct control of the Forestry Department of Fujian Province, instead of the government of Wuyishan City.

104. Lv, Z.M. New thoughts on legislation of protected areas. Environ. Ecol. Netw. Environ. Prot. 2019, 3, $20-23$.

105. Zhang, H.W.; Yang, R. Discussion on some issues of the legislation for national parks and protected areas in China. Chin. Gard. 2016, 2, 70-73.

106. Wang, Y.; Huang, B.R. Reform of national parks system in China: Review and prospect. Biodivers. Sci. 2019, 27, 117-122.

107. Liu, C. Legal expression of the natural reserve system with national park as the main body. J. Jishou Univ. 2019, 5, 81-92.

108. Pimber, M.L.; Pretty, J.N. Passive participation' means people participate by being told what is going to happen or what has already happened, but they have no opportunity to change them. Parks people and professionals: Putting "participation" into protected area management. In Social Change and Conservation: Environmental Politics and Impacts of National Parks and Protected Areas; Ghimire, K.B., Pimber, M.P., Eds.; Earthscan: London, UK, 1997; pp. 297-330.

109. Zhao, L.L. 'Self-Mobilization Participation' Means People Participate by Taking Initiatives Independent of External Institutions to Change Systems. The "Self-Mobilization Participation" Also Means All the Relevant Parties Actively Participate in the Whole Process and Take Their Possible Reasonable Responsibilities. The Community-based Management on Fishery in China. Ph.D. Thesis, Ocean University of China, Qingdao, China, 2009.

110. The "Notification on Further to Strengthen Hydropower Construction and Environmental Protection" [关 于进一步加强水电建设环境保护的通知] was issued on 6 January 2012 by the Ministry of Environmental Protection of the People's Republic of China. This notification can be regarded as a policy, but it helps to forbid some economic activities in protected areas in China.

111. Xinhua Net. The department of environmental protection response to environmental groups events: It is rule of development. Posted on 12 November 2012.

112. Lang, H.L. As for analysis of the public participation provisions in the new EPL, Public participation in environmental decision-making in China: Towards an ecosystem approach. Int. Biodeterior. 2014, 95, 356-363.

113. "Government oriented, common participation" means the government play a leading role in protected areas establishment and management and local peoples, experts, enterprises, social organizations are also invited to actively participate in the whole progress of national parks establishment and management.

114. The "Hubei Xingdoushan National Nature Reserve Management Regulation in Enshi Tujia and Miao autonomous prefecture" was issued on 30 July 2010. 
115. Conservation, Human Rights \& Protected Areas Governance: A Field-Based Workshop in the Baviaanskloof Mega-Reserve. South Africa. 6-7 July 2007. Available online: http://cmsdata.iucn.org/downloads/bav_ workshop.pdf (accessed on 10 October 2012).

116. Tang, F.L. Thoughts on the system construction of national parks with Chinese characteristics. For. Constr. 2018, 5, 86-96.

117. The pilot reform plan of the Sanjiangyuan national park system was examined and approved at the central level at the end of 2015. Since then, China's first national park pilot program was officially launched.

118. Zhuang, Y.B.; Yang, R.; Zhao, Z.C. Preliminary analysis on the implementation plans for the Chinese national park pilot areas, China. Chin. Landsc. Archit. 2017, 33, 5-11. (In Chinese)

119. Zero draft of the post-2020 global biodiversity framework. In Proceedings of the Open-Ended Working Group on the Post-2020 Global Biodiversity Framework Second Meeting, Kunming, China, 24-29 January 2020. CBD/WG2020/2/3.

(C) 2020 by the authors. Licensee MDPI, Basel, Switzerland. This article is an open access article distributed under the terms and conditions of the Creative Commons Attribution (CC BY) license (http://creativecommons.org/licenses/by/4.0/). 